\title{
Silage review: Using molecular approaches to define the microbial ecology of silage ${ }^{1,2}$
}

\author{
T. A. McAllister, ${ }^{* 3}$ L. Dunière,†‡ P. Drouin,§ S. Xu, ${ }^{*}$ Y. Wang, ${ }^{*}$ K. Munns, ${ }^{*}$ and R. Zaheer* \\ *Agriculture and Agri-Food Canada, Lethbridge Research and Development Centre, Lethbridge, AB, Canada T1J 4B1 \\ tLallemand Animal Nutrition, Blagnac 31702, France \\ †UMR 454 MEDIS INRA-UCA, Clermont-Ferrand 63122, France \\ §Lallemand Specialties Inc., 6120 West Douglas Avenue, Milwaukee, WI 53218
}

\begin{abstract}
Ensiling of forages was recognized as a microbialdriven process as early as the late 1800 s, when it was associated with the production of "sweet" or "sour" silage. Classical microbiological plating techniques defined the epiphytic microbial populations associated with fresh forage, the pivotal role of lactic acid-producing bacteria in the ensiling process, and the contribution of clostridia, bacilli, yeast, and molds to the spoilage of silage. Many of these classical studies focused on the enumeration and characterization of a limited number of microbial species that could be readily isolated on selective media. Evidence suggested that many of the members of these microbial populations were viable but unculturable, resulting in classical studies underestimating the true microbial diversity associated with ensiling. Polymerase chain reaction-based techniques, including length heterogeneity PCR, terminal RFLP, denaturing gradient gel electrophoresis, and automated ribosomal intergenic spacer analysis, were the first molecular methods used to study silage microbial communities. Further advancements in whole comparative genomic, metagenomic, and metatranscriptomic sequencing have or are in the process of superseding these methods, enabling microbial communities during ensiling to be defined with a degree of detail that is impossible using classical microbiology. These methods have identified new microbial species in silage, as well as characterized shifts in microbial communities with forage type and composition, ensiling method, and in response to aerobic exposure. Strain- and species-specific primers have been used to track the persistence and contribution of silage inoculants to the ensiling process and the role of specific species of yeast and fungi in silage spoil-
\end{abstract}

Received August 18, 2017.

Accepted October 21, 2017.

${ }^{1}$ All authors contributed equally to this review.

${ }^{2}$ This article is part of a special issue on silage management.

${ }^{3}$ Corresponding author: tim.mcallister@agr.gc.ca age. Sampling and the methods used to isolate genetic materials for further molecular analysis can have a profound effect on results. Primer selection for PCR amplification and the presence of inhibitors can also lead to biases in the interpretation of sequence data. Bioinformatic analyses are reliant on the integrity and presence of sequence data within established databases and can be subject to low taxonomic resolution. Despite these limitations, advancements in molecular biology are poised to revolutionize our current understanding of the microbial ecology of silage.

Key words: silage, microbial ecology, biotechnology, microbiome

\section{INTRODUCTION}

Ensiling of forages has become a global practice for forage preservation and is particularly prevalent in wet climates, where the conservation of dried forage is difficult (Pahlow et al., 2003). The microbiome associated with freshly harvested forage plays a critical role in the ensiling process and is composed of a complex mixture of bacteria, yeasts and molds with colony-forming units ranging from $10^{5}$ to $10^{9} \mathrm{cfu} \cdot \mathrm{g}^{-1}$ (Langston and Bouma, 1960a,b,c). Once introduced into the silo, the diversity of the microbiome decreases as obligate aerobes and acid-sensitive microbes are killed or fail to grow as oxygen is excluded and acid production reduces $\mathrm{pH}$. Under these conditions, epiphytic lactic acid-producing bacteria (LAB), enterobacteria, yeasts, and molds can enter a viable but unculturable state precluding their characterization through traditional plating methods. Epiphytic and spoilage microbial populations associated with the ensiling process are exceedingly complex, requiring significant effort to characterize members in detail on the basis of morphological, physiological, and biochemical traits. To assess the composition of bacterial communities associated with plants, a wide variety of techniques, both culture-based (e.g., most probable number, selective media, biochemical profiling, and so on) as well as culture-independent analyses of microbial 
communities using techniques such as denaturing gradient gel electrophoresis (DGGE), single strand conformation polymorphisms, terminal RFLP (T-RFLP), automated ribosomal intergenic spacer analysis, or length heterogeneity PCR have been employed for the past decade. In addition, polyphasic/multipronged approaches, using multiple techniques in parallel, have also been used to thoroughly characterize the structure and diversity of silage microbial communities (Brusetti et al., 2008).

Advances in deep sequencing using a variety of platforms (e.g., Ilumina, Roche 454, Ion Torrent, PacBio) now make it possible to undertake metagenomic sequencing of microbial DNA extracted from freshly harvested forage (Eikmeyer et al., 2013), during ensiling (Bao et al., 2016), upon aerobic exposure (Dunière et al., 2017), and even from the rumen after consumption of silage by ruminants (Huws et al., 2015). These techniques have generated new insight into the complexity of the microbial ecology of ensiling, characterizing the role of epiphytic populations in silage quality and how silage additives can generate microbiomes more conducive to the production of high-quality silage. Quantitative PCR (qPCR) can be used to specifically quantify and document the persistence of specific phylogenies, species, or even strains of bacteria and fungi during ensiling and feed out. Consequently, the growth and survival of inoculated bacteria can now be differentiated from their epiphytic counterparts, generating a greater understanding of how these specific strains favorably alter the ensiling process. Using these techniques to identify mycotoxin-producing fungal populations or potential pathogens such as Listeria spp. in silage could provide new approaches to excluding these undesirable microorganisms from silage.

Presently, most studies have been confined to study the phylogeny of microbes using $16 \mathrm{~S}$ rRNA or $18 \mathrm{~S}$ rRNA/internal transcribed spacer (ITS) regions for the classification of bacterial and fungal populations, respectively. Although these studies provide a wealth of information on the microbial ecology of silage, they provide limited information on the function of the microbial species involved in the ensiling process. Future use of metatranscriptomics to characterize the ensiling process could shed insight into the expression of genes coding for enzymes involved in silage acid production and metabolism, proteolysis, or the production of mycotoxins during silage spoilage.

Although molecular techniques are poised to revolutionize our understanding of the role of microorganisms in ensiling, the scientific integrity of the information generated depends on the representativeness and purity of the nucleic acids that are extracted from the forage.
The nature of the primers selected for amplification of genetic regions of interest, the presence of PCR inhibitors and the selected sequencing platform can all influence the nature of the results generated. Once sequence information is obtained, the breadth and depth of the bioinformatic pipelines and limits of the gene databases used in the interpretation of data can affect predicted outcomes. The objective of this review is to outline some of the molecular methodologies currently being employed in the area of silage ecology and how they will advance the field of silage science both now and in the future.

\section{SAMPLING, STORAGE, AND EXTRACTION METHODOLOGIES}

\section{Sampling Methods}

Many of the same sampling principles of acquiring silages for nutrient analysis are applicable to collecting silage samples for molecular analysis (Undersander et al., 2005). For fresh forage, 3 to 5 samples can be collected after the truck or wagon has been unloaded. Samples can be mixed and a single sample collected for storage as described below. This procedure can be repeated 4 to 5 times at regular intervals as silage is delivered for ensiling throughout the day. For bunker of bag silos, 150 to $300 \mathrm{~cm}$ of silage should be removed from the silo face to create a pile to sample from. If spoiled silage is not the subject of interest in the study, care should be taken to ensure that it is not collected during the sampling procedure. Five to 8 samples can be selected from the pile and mixed within a bucket before sampling and storage as described below. A total of 3 to 6 samples should be collected in this manner. If a microbial profile of the silage within the entire silo is desired, this procedure should be repeated at regular intervals during feed out.

\section{Extraction Methods and Storage}

One of the important factors in planning PCR-based studies or undertaking amplicon- or shotgun-based metagenomic or metatranscriptomic sequencing is to ensure that the extraction protocol employed obtains the quality and yield of nucleic acids needed to generate high-quality sequences. Ideally, samples should be frozen immediately after collection and stored in an ultra-low-temperature freezer to impede microbial activity, sustain cellular integrity, and ensure that the microbial diversity profile remains stable during storage. Short-term storage (14 d) of biological samples at temperatures ranging from -80 to $20^{\circ} \mathrm{C}$ has been 
shown to have little effect on phylogenetic structure and diversity (Lauber et al., 2010; Rubin et al., 2013), but longer term storage ( $>50 \mathrm{~d}$ ) can alter these metrics even if samples are frozen (Molbak et al., 2006; Bahl et al., 2012). The greater instability of RNA than DNA is likely to amplify these differences in transcriptomic silage studies. These studies stress the importance of maintaining consistency in silage sample storage within a study and the potential limitations of comparing findings across studies that use different storage protocols.

The yield of nucleic acids extracted from silage depends on the types of silage, the growth of microbial cells during ensiling, the diversity and abundance of microorganisms within the silage, and the stability of the nucleic acids. Microorganisms do not grow uniformly throughout the silage mass as regions of high soluble carbohydrate or protein content may result in focal areas of high microbial abundance in the form of biofilms (Figure 1). Microbes also often invade into the interior of plant cell walls where the concentration of soluble nutrients are high, using an inside-out approach to plant cell wall digestion (McAllister et al., 1994), making it difficult to adequately extract them from the silage mass through simple washing with a buffer. Consequently, silage samples collected for molecular analysis should preferably be immediately frozen and lyophilized, rather than oven-dried where microbial populations may shift and the stability of nucleic acids reduced. For DNA, dried samples can be ground and ball milled before extraction. Although this procedure renders microorganisms more available for DNA extraction, it also increases the amount of residual plant DNA that is co-isolated. This can reduce the microbial DNA to plant DNA ratio, potentially lowering the sensitivity of the analysis. It also requires a greater effort to ensure that plant-based genetic information is filtered out during bioinformatic analysis. Due to the instability of RNA, it is desirable that silage samples are immediately frozen in liquid nitrogen and ground in liquid nitrogen to a fine powder so as to maximize RNA yields (Wang et al., 2011).

Another option is to use a liquid-based extraction method to harvest microbial cells from forage and silage before nucleic acid isolation (Eikmeyer et al., 2013). This technique involves multiple washes (5-10) of forage or silage samples in physiological saline. The pooled extracts are then centrifuged to collect the cells, immediately subjected to DNA extraction, or can be preserved in ethanol in an ultra-low-temperature freezer (Martinez Tuppia et al., 2017). This procedure makes it easier to remove residual plant tissue before isolation of microbial cells, thus lowering the degree of contamination by plant DNA. The drawback is that some microbial cells remain trapped inside the plant tissue as biofilms also form in the interior vasculature of plants (Bogino et al., 2013). Consequently, they may not be released into the liquid medium before the collection of microbial cells via centrifugation.

\section{DNA Extraction Procedures}

The cetyl trimethyl ammonium bromide (CTAB) method was originally designed for the extraction and purification of DNA from plants. This cationic detergent-based method solubilizes cell polysaccharides and denatures proteins, improving the release of DNA from the plant cell and yield of extracted DNA (Kumar et al., 2014; Ashwini and Tiwari, 2015). The addition of polyvinylpyrrolidone to the extraction procedure further improves DNA yields as it binds to polyphenolics and reduces the formation of phenolic-nucleic acid complexes. The reduced number of steps required by the CTAB method also helps maintain the strand length of the DNA, favoring the generation of longer reads during sequencing. The CTAB procedure is also ideal for processing forage and silage samples that have been pulverized in liquid nitrogen or ground after lyophilization as it is efficient at removing residual plant components. However, after extraction of DNA from forage or silage, a secondary cleanup of the isolated nucleic acids is often required to ensure that PCR inhibitors have been removed. Consequently, many laboratories have elected to use commercial kits for the extraction of DNA/RNA from silage samples.

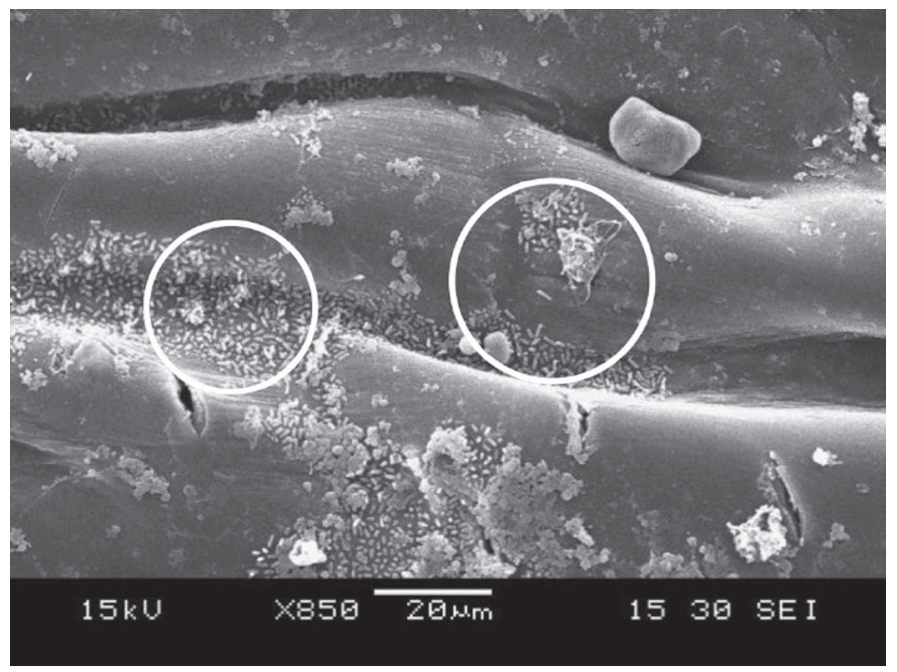

Figure 1. Scanning electron micrograph of corn silage collected from a commercial type bunker silo. Bacterial cells are present as biofilms (circles) on the surface of a leaf fragment. Micrograph courtesy of Lallemand SAS Inc.; used with permission. 


\section{DNA Extraction Kits}

The processes of DNA/RNA extraction have been simplified by several commercial companies developing extraction and purification kits. A plethora of commercial kits are available from several different suppliers (e.g., Qiagen, MoBio, MP Biomedicals, Zymo Research) making it challenging to select those that are optimal for the extraction of nucleic acids from silage. Both fresh forage and silage contain a variety of PCR inhibitors that interfere with both amplicon and shotgun sequencing. Consequently, kits that have specific steps aimed at removing PCR inhibitors such as those used in the extraction of nucleic acids from soil or stools tend to be most suitable for fresh forages and silages.

We are unaware of studies that have specifically assessed the efficiency of various commercial kits to extract DNA/RNA from silages. It is almost certain that the nature of the extraction kits selected can alter the interpretation of the phylogenetic profile associated with silages as such a response has been observed with other environmental samples. For example, a recent comparison of extraction efficiencies of kits from permafrost soils found similar phylogenetic profiles among kits that employed bead beating, whereas kits that did not include this procedure identified a higher proportion of $\beta$-Proteobacteria and $\gamma$-Proteobacteria (Vishnivetskaya et al., 2014). The DNA yield also differed among extraction kits, with the FastDNA Spin kit having twice the yield of the MoBio kit, likely as result of its ability to more efficiently lyse bacterial cells.

Others have compared the efficiency of various extraction kits from agricultural soils (Pakpour et al., 2013). These authors concluded that those kits that did not specifically use bead beating reduced the degree of DNA fragmentation while still generating acceptable yields. Pakpour et al. (2013) proposed that eliminating bead beating reduced DNA fragmentation and improved sequencing efficiency, but did not specifically test this hypothesis.

Obviously, for microorganisms to be detected, DNA/ RNA must be liberated from the cell and captured during the extraction and purification process. The cell wall structure differs between gram-positive and gramnegative bacteria with the cell wall of gram-positive bacteria being generally more difficult to disrupt owing to a thick layer of peptidoglycan. Thus, protocols that do not use a bead beating can underestimate both the abundance and diversity of gram-positive bacteria within silages. This is particularly relevant with regard to obtaining adequate representation of the grampositive lactobacilli that play a pivotal role in the ensiling process. Some commercial kits contain chemicals (e.g., lysozyme, mutanolysin, and proteinase K) that promote lysis particularly at elevated temperatures $\left(50-70^{\circ} \mathrm{C}\right)$. Although these methods can improve the yield of DNA/RNA from gram-positive bacteria, differences in extraction procedures from biological samples can generate significant differences in microbial profiles (Henderson et al., 2013). Extraction procedures need to be employed with an appreciation that longer and more vigorous bead beating procedures are likely to increase yield, at the expense of greater fragmentation of DNA. Further investigation of the effect of different commercial kits on the extraction of DNA from different types of silage should be undertaken.

\section{USE OF PCR IN THE MOLECULAR ANALYSIS OF SILAGE}

Practically all DNA-based techniques, commonly called "culture-independent analysis," require the amplification of genes by PCR. Muck (2013) recently reviewed the main techniques that have been used to characterize the molecular microbial ecology of silage. Amplicon-based PCR amplifies a targeted segment of DNA through the design of forward and reverse primers that flank the region of interest. PCR-based molecular amplification methods have broad applications as they can be used to identify a particular species and distinguish between multiple microbial species (conventional PCR, in combination with Sanger sequencing of PCR products) as well as to quantify a particular species or overall bacterial populations (real-time or qPCR). Real-time or qPCR enables the elimination of laborious post-amplification steps such as the use of gel electrophoresis to visualize amplified products following conventional PCR. Overall, the benefits of $\mathrm{qPCR}$ as compared with conventional PCR include sensitivity, reproducibility, speed, and quantitative ability. However, these applications require designed primers that are appropriate for the target of interest. Factors such as primer specificity and the length of the fragment to be amplified can influence the efficiency of PCR.

Although PCR is an invaluable tool for defining the microbial ecology of silage, it is possible for biases to occur if conditions are such that one targeted fragment is more efficiently amplified than another. Biases related to amplification and primer mismatch can be reduced by using tag-based sequencing, and this approach has the added benefit of simultaneously generating both taxonomic and functional information (Logares et al., 2014).

\section{PCR Target(s) for Taxonomic Identification}

The ribosomal RNA genes present in either single or multiple copies are essential for the survival of all 
Bacteria

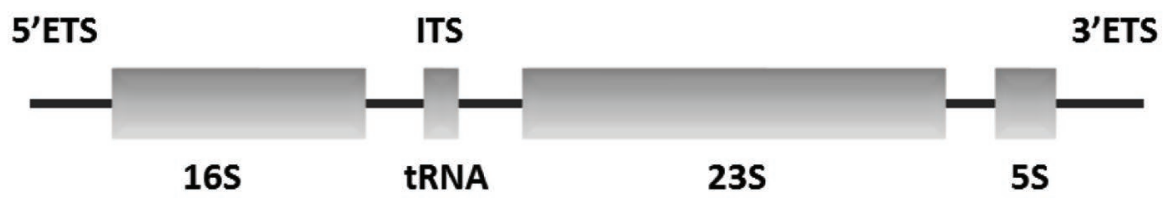

Eukaryotes

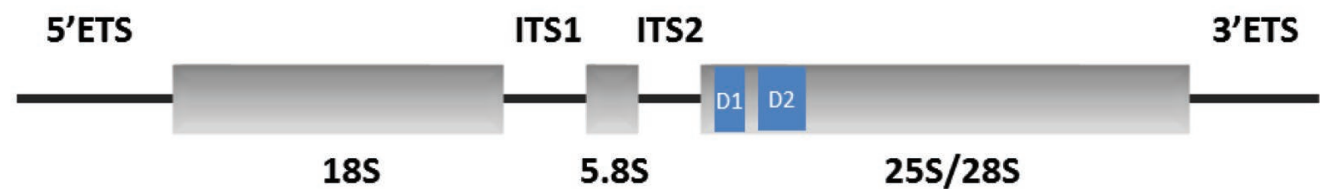

Figure 2. Conserved organization of the rRNA operon in bacteria and eukaryotes. In the pre-rRNA, the mature rRNA sequences are flanked by external transcribed spacers (5' ETS and 3' ETS) and separated by one or more internal transcribed spacers (ITS). Color version available online.

organisms and are generally highly conserved between all living organisms. The bacterial ribosomal RNA operon is transcribed into one pre-rRNA transcript that contains the small subunit (SSU or 16S), the large subunit (LSU or 23S), and the 5S rRNA sequences (Figure 2). Both 16S and 23S ribosomal genes have been widely used for species identification and strain detection. Since it was first used in 1985 for phylogenetic analysis (Lane et al., 1985), the sequences of $16 \mathrm{~S}$ rRNA genes have been by far the most frequently used taxonomic marker. The $16 \mathrm{~S}$ rRNA genes generally contain 9 hypervariable regions (V1-V9) interspersed by conserved sequences (Figure 3). The hypervariable regions demonstrate considerable sequence diversity among different bacterial species and can be used for species identification (Van de Peer et al., 1996). The conserved sequences flanking the $\mathrm{V}$ region enable PCR amplification of target sequences using universal primers (McCabe et al., 1999; Baker et al., 2003). Furthermore, the variations in length and sequence of the 16S-23S rRNA intergenic spacer regions of the rRNA operon have proven useful for identification of closely related strains and species. For example, this region has been used to differentiate closely related species of lactic acid bacteria (Furet et al., 2004; Klocke et al., 2006). This is a reflection of the rapid rate of evolution within this region, which has been estimated to be 10 times that of 16S rRNA (Gürtler and Stanisich, 1996). However, in cases where the $16 \mathrm{~S}$ rDNA or $16 \mathrm{~S}$ rRNA genes cannot differentiate closely related species due to high homology, other more divergent loci such as chaperonin-60 (CPN-60; Links et al., 2012) and recA (Stevenson et al., 2006; Hofstatter et al., 2016) may be used to characterize bacterial diversity.

The eukaryotic rRNA operon consists of the SSU (18S) and the LSU (25S/28S), separated by an ITS region comprising of 2 sections ITS1 and ITS2 that flank the conserved 5.8S region (Figure 2). Molecular characterization of yeast and mold populations in silage have used 18S rRNA (Li and Nishino, 2011a,b), 26S rRNA (Liu et al., 2013), or ITS regions (Rossi and Dellaglio, 2007). The earliest PCR primers that gained wide acceptance for fungal detection were ITS1, which targets a site in the ribosomal small subunit encoding region, and ITS4, which targets an ITS-flanking site in the LSU (White et al., 1990). During the past 2 decades, molecular identification through DNA barcoding of fungi has provided new insights into the diversity

\begin{tabular}{|l|l|c|c|c|c|c|c|c|c|c|c|c|c|c|c|c|c|}
0 & 100 & 200 & 300 & 400 & 500 & 600 & 700 & 800 & 900 & 1000 & 1100 & 1200 & 1300 & 1400 & 1500 bp \\
\hline V1 & V2 & & V3 & & V4 & V5 & & V6 & & V7 & & V8 & & V9 & \\
\hline
\end{tabular}

\section{Conserved regions}

\section{Variable regions}

Figure 3. Organization of hypervariable and conserved regions of 16S rRNA gene. 
and ecology of many different groups of fungi and has become an essential part of fungal ecology research (Horton and Bruns, 2001; Anderson and Cairney, 2004; Chase and Fay, 2009). During the early years of barcoding, the ITS region was used as a default marker for fungal species, whereas the LSU became the standard for the identification of yeast. In recent years, studies have identified potential amplification biases dependent on the choice of ITS primers, leading to the preferential amplification of certain fungal groups. It has been suggested by Bellemain et al. (2010) that ITS primers should be selected carefully, especially when used for high-throughput sequencing of environmental samples and that different primer combinations or different parts of the ITS region should be analyzed in parallel. The authors also illustrate potential benefits of using a bioinformatics approach before selecting primer pairs for a given study, although an in silico analysis did not necessarily reflect the performance of the primers in vitro. This is because many other PCR parameters such as ITS copy number, amplification program, and salt and primer concentrations during PCR are often not considered by in silico predictions. Other studies suggest that a multi-region approach for primer design including the ITS and the variable D1/D2 region of the LSU (Figure 2) may prove more discriminatory (Tonge et al., 2014). Fewer hypervariable domains within the $18 \mathrm{~S}$ rDNA region in fungi may result in lower efficiencies of taxonomic assignment (Anderson et al., 2003; Schoch et al., 2012) as compared with the use of $16 \mathrm{~S}$ rDNA region in bacteria.

\section{Nonspecific Binding}

Designing a new primer, as well as testing primers from the literature needs to be undertaken to ensure that they cannot bind to nonspecific sites. Those DNA regions could be either noncoding regions as well as the region of the target gene present in a distinctly related genus. Online tools such as Primer-BLAST enable primers to be evaluated by searching for similar genes within the database. During the designing phase, it is important to assess the extent of alignment of the target gene with a broad set of sequences. In practice, further testing of the specificity of the designed primers using the culturable strains or species is desirable if they are available.

\section{PCR Inhibitors}

Polymerases are often inhibited by contaminants that are isolated during DNA extraction. Both inorganic and organic substances can act as PCR inhibitors (Schrader et al., 2012), but those that are particularly relevant to fresh forage and silages include polysaccharides, proteases, phenolics, and tannins, with phenolics and tannins being potent inhibitors of reverse transcription (RT)-PCR (Love et al., 2008). In most instances, the effect of inhibitors can be reduced through dilution, using the cleanup procedures recommended within commercial kits, by adding BSA during extraction or through addition of column extraction steps (Reuter et al., 2009). However, we have found that legume forages that contain condensed tannins such as sainfoin or birdsfoot trefoil can still inhibit metatranscriptomic sequencing even after attempts are made to remove these inhibitors (T. A. McAllister laboratory, unpublished data).

\section{MOLECULAR APPROACHES TO DEFINING THE MICROBIAL ECOLOGY OF SILAGE}

\section{Strain Tracking and Quantification}

Although the microbial diversity in silage is often low, plate counts are not reliable for tracking specific species of microorganisms during ensiling or feed out due to the limited characterization at the species level of most culture techniques. Quantitative PCR can be used to track and quantify both bacteria and fungi during ensiling. Quantitative PCR targeting 16S rDNA was first used to estimate the development of the Lactobacillus plantarum populations within grass silages (Klocke et al., 2006). These researchers demonstrated that grass silages inoculated with L. plantarum or precision chopped harbored larger populations of this species, which were reduced by acid treatment of the silage. Stevenson et al. (2006) expanded on this approach, designing species-specific primers for qPCR of recA, to identify several Lactobacillus spp. as well as Enterococcus faecium, Pediococcus pentosaceus, and Bacillus subtilis in alfalfa silage. Their findings showed that Lactobacillus brevis was the dominant species observed (up to $32 \%$ ), whereas L. plantarum, P. pentosaceus, Lactobacillus buchneri, and Lactobacillus lactis represented much smaller proportions of the population, whereas both Lactobacillus pentosus and E. faecium were undetectable. The method was also assessed for its ability to detect $L$. buchneri in inoculated silage and was capable of detecting as few as $100 \mathrm{cfu} \cdot \mathrm{g}^{-1}$ of corn silage (Schmidt et al., 2008). The results showed that the numbers of L. buchneri in terminal corn silage estimated by RT-qPCR were similar to the total culturable LAB, suggesting that this inoculated species dominated the ensiling process. In contrast, Lynch et al. (2012) found that inoculation with L. buchneri 11A44 had little effect on the ensiling of corn ears and 
stover and did not increase the number of $L$. buchneri in the later stages of ensiling, possibly due to competition with naturally high epiphytic populations. Others have found that estimated copy numbers of L. buchneri can approach the copy numbers associated with total bacteria in silage, possibly due to differences in the PCR efficiency among amplicons or non-target-specific amplification (Dunière et al., 2015). These researchers also used RT-qPCR to monitor the fate of inoculated Saccharomyces cerevisiae and Saccharomyces paradoxus during the ensiling and upon aerobic exposure. Although this study showed that the copy number of these yeasts did not increase during the ensiling period, increases of these species during aerobic exposure did demonstrate that they were capable of surviving the ensiling process.

Although RT-qPCR is an invaluable tool for quantifying microorganisms during ensiling, it also has some inherent limitations. Microbial numbers based on RT-qPCR may be overestimated compared with plate counts as the copy numbers of $16 \mathrm{~S}$ rDNA or rRNA genes in bacteria (Case et al., 2007) and 18S rDNA, $28 \mathrm{~S}$ rDNA, and ITS genes in fungi and yeast (Lindahl et al., 2013) vary among species. Furthermore, DNA from nonviable microorganisms can also be amplified and quantified, overestimating the true metabolically active microbial population within silage.

\section{Community Analysis}

The development of molecular fingerprinting techniques provided a pattern or profile of the genetic diversity in a microbial community based on the physical separation of unique nucleic acid sequences. All of these techniques still rely on the amplification of target genes by PCR, followed by the use of various methods to separate the resulting amplicons.

Denaturing gradient gel electrophoresis separates DNA fragments of identical length, but with different nucleotide sequences (Pedro et al., 2001) and has been used to define the nature of bacterial communities in ryegrass, alfalfa and corn silages (Dolci et al., 2011; Wu et al., 2014; Ni et al., 2017). The technique has been applied to both bacterial and fungal communities, but as it uses gel electrophoresis it is more qualitative than quantitative. Selection of primers designed for specific microorganisms can expand the potential of DGGE to study the diversity of a particular group or a genus (Julien et al., 2008; Zhou et al., 2016).

Early techniques used variation in gene length as a means of attempting to differentiate bacterial species in silage. Brusetti et al. (2008) used length heterogeneity PCR to examine shifts in the LAB population during the ensiling of corn. Terminal-RFLP advanced this ap- proach by employing restriction enzymes to specifically cut the amplified DNA into varying lengths. The resulting DNA fragments were separated by either capillary or gel electrophoresis with differentiation based on the length of the fragments (McEniry et al., 2008). Compared with DGGE, T-RFLP DNA fragments could not be easily excised from gels, but could be visualized and semi-quantified if analyzed using capillary techniques (McEniry et al., 2008). Automated ribosomal intragenic spacer analysis refined the T-RFLP procedure by specifically amplifying a region between the $16 \mathrm{~S}$ rRNA and 23S rRNA gene in bacteria (Brusetti et al., 2008). Of the methods that differentiated microbial populations based on gene length, automated ribosomal intergenic spacer analysis appeared to have the greatest resolution owing to the fact that a region of greater variability was amplified. However, the advent of next-generation sequencing (NGS) methods has largely resulted in molecular fingerprinting techniques becoming antiquated. New NGS methods have far superior resolution and are more adept at describing diversity. They are also often considerably cheaper in terms of both labor and reagent costs.

Metagenomics. Metagenomics is defined as culture independent, direct genetic analysis of genomes within environmental samples (Thomas et al., 2012). Advances in the NGS have revolutionized the field of microbial ecology. Two types of NGS-based metagenomics studies are commonly conducted: (1) single/marker-gene amplification metagenomics, more appropriately called "metaprofiling" or amplicon-based profiling (e.g., 16S rRNA gene in prokaryotes), and (2) whole shotgun metagenomics. These methods allow profiling of the whole microbial community including uncultivable species and can generate an in-depth description of microbial diversity within various ecosystems at a reasonable cost. Marker gene-based metaprofiling generates taxonomic and phylogenetic classification of microorganisms in complex ecosystems with less investment in time and computational power ( $\sim 50,000$ reads/sample) than whole shotgun metagenomics. Other advantages of metaprofiling over whole metagenomics include cheaper sequencing costs, and no (eukaryotic) contamination with host DNA as a result of target-specific amplification of conserved regions (e.g., 16S rRNA gene, CPN60 gene). However, it has certain limitations as primer selection can result in biases toward certain members within microbial communities and resolution is often insufficient to identify bacteria to the strain or even the species level. In addition, different primers are required for multi-domain communities that harbor bacteria, archaea, and eukaryotes, and no marker genes are available to amplify and differentiate members within the virome. 
Amplicon-based studies such as 16S rDNA metaprofiling depend on annealing of amplification primers to conserved regions that flank variable regions of the $16 \mathrm{~S}$ rRNA gene (Figure 3). Regardless of sequencing depth, the variable region selected for amplification and amplification bias can confound the quantitative assessment of bacterial community dynamics including taxonomic classification, operational taxonomic unit (OTU) richness, and OTU diversity (Huse et al., 2008; Claesson et al., 2009; Pinto and Raskin, 2012). Different variable regions have been targeted in different studies resulting in diverse findings. For example, Sundquist et al. (2007) favored the V1/V2/V4 regions, Liu et al. (2008) the $\mathrm{V} 2 / \mathrm{V} 3 / \mathrm{V} 4$ regions, Wang et al. (2007) the V2/V4 regions, Chakravorty et al. (2007) the V2/V3 regions, and Yang et al. (2016) the V4/V6 region. Myer et al. (2016) recommended V1/V8 near-full length over the V1/V3 region as it resulted in increased phylogenetic resolution, improved differential taxonomic classification, and was more adept at taxonomic classification and at identifying differences in community composition.

Using full-length $16 \mathrm{~S}$ rRNA genes $(\sim 1,500 \mathrm{bp})$ is considered the gold standard for accurate taxonomic identification (Vinje et al., 2015). Presently, such an approach is often cost prohibitive as compared with targeting a single variable region. To generate fulllength high-quality reads, sequencing with the Pacific Biosciences RSII instrument is required at a cost per read that is much higher than sequencing smaller regions such as V1-V3 or V3-V5 using short-read platforms such as Illumina MiSeq or Ion Torrent (Myer et al., 2016). The cost barrier to increased read lengths may be overcome with emerging nanopore sequencing technologies (Steinbock and Radenovic, 2015) or microfluidic sequencing (Streets et al., 2014).

Although marker gene (e.g., 16S rRNA, 18S rRNA, and ITS) sequencing has been widely used to describe microbial communities and programs such as Phylogenetic Investigation of Communities by Reconstruction of Unobserved States (PICRUSt; Langille et al., 2013) have been used to predict their functionality, such an approach does not generate a complete genetic profile of microbial populations. In contrast, shotgun metagenomic sequencing of the DNA isolated from a sample provides thorough genetic information of microbial communities as well as genomic linkages between the function and phylogeny of uncultured organisms (Tennant et al., 2017). Shotgun metagenomics avoids primer biases as all microbes in the community including eukaryotes and viruses can be sequenced and identified. In addition to providing community composition, it also helps generate information on the function of the community. However, some of the disadvantages include very high cost of deep sequencing to generate millions of reads, host/site contamination, lack of information on "rare" species due to limitations of deep sequencing, and complex bioinformatics algorithms that require significant computational resources. Examples of the taxonomic profilers for whole metagenomics sequence data include Kraken (Wood and Salzberg, 2014), CLARK (Ounit et al., 2015), and Taxonomer (Flygare et al., 2016).

Although NGS has been widely used to characterize the microbial ecology of soil (Keshri et al., 2013), the rhizosphere (Bulgarelli et al., 2012), and the bovine rumen (Hess et al., 2011), it has only recently been used to characterize the microbial ecology of silage. As the fermentation of silage is largely a bacterial-driven process and considering that the databases used to curate bacterial populations are more robust than those for fungi, the majority of metagenomics studies have focused primarily on the bacterial ecology of silage (Table 1). Metagenomics has been used to describe the evolution of bacterial populations during the ensiling process, with a focus on comparing epiphytic populations on fresh forage to those associated with terminal silage. Some studies have described the effect of silage inoculants (Eikmeyer et al., 2013; Bao et al., 2016; Romero et al., 2017; Ogunade et al., 2017), whereas others have described differences among bacterial populations during the ensiling of different forage types (Mogodiniyai Kasmaei et al., 2016; Dunière et al., 2017; Ni et al., 2017) or temporal and spatial variability of microbial communities in silages stored in bunkers (Kraut-Cohen et al., 2016).

Eikmeyer et al. (2013) were the first to use NGS to study bacterial populations in silage, comparing noninoculated to LAB-inoculated grass silages. They observed a decrease in bacterial diversity over the duration of the ensiling process. This reduction in bacterial diversity has then been observed in other studies with different silage crops and ensiling duration (Mogodiniyai Kasmaei et al., 2016; Ni et al., 2017; Romero et al., 2017, Dunière et al., 2017). The nature of the epiphytic bacterial population is highly influenced by the type of forage ensiled (Mogodiniyai Kasmaei et al., 2016; Dunière et al., 2017), but typically the bacterial population proceeds toward a predominance of lactobacilli during the ensiling process, particularly in grain silages. Pre-ensiling, OTU belonging to the Lactobacillaceae family associated with Italian ryegrass and whole crop corn accounted for 1 to $2 \%$ of the bacterial population, but after ensiling they made up 15 to $25 \%$ and up to $70 \%$ of the bacterial population, respectively ( $\mathrm{Ni}$ et al., 2017). In contrast, the bacterial population of oat silage was dominated by Leuconostocaceae pre-ensiling (83\%) with the relative abundance of this family accounting for $95.8 \%$ of the bacterial population in terminal silage 
MCALLISTER ET AL.

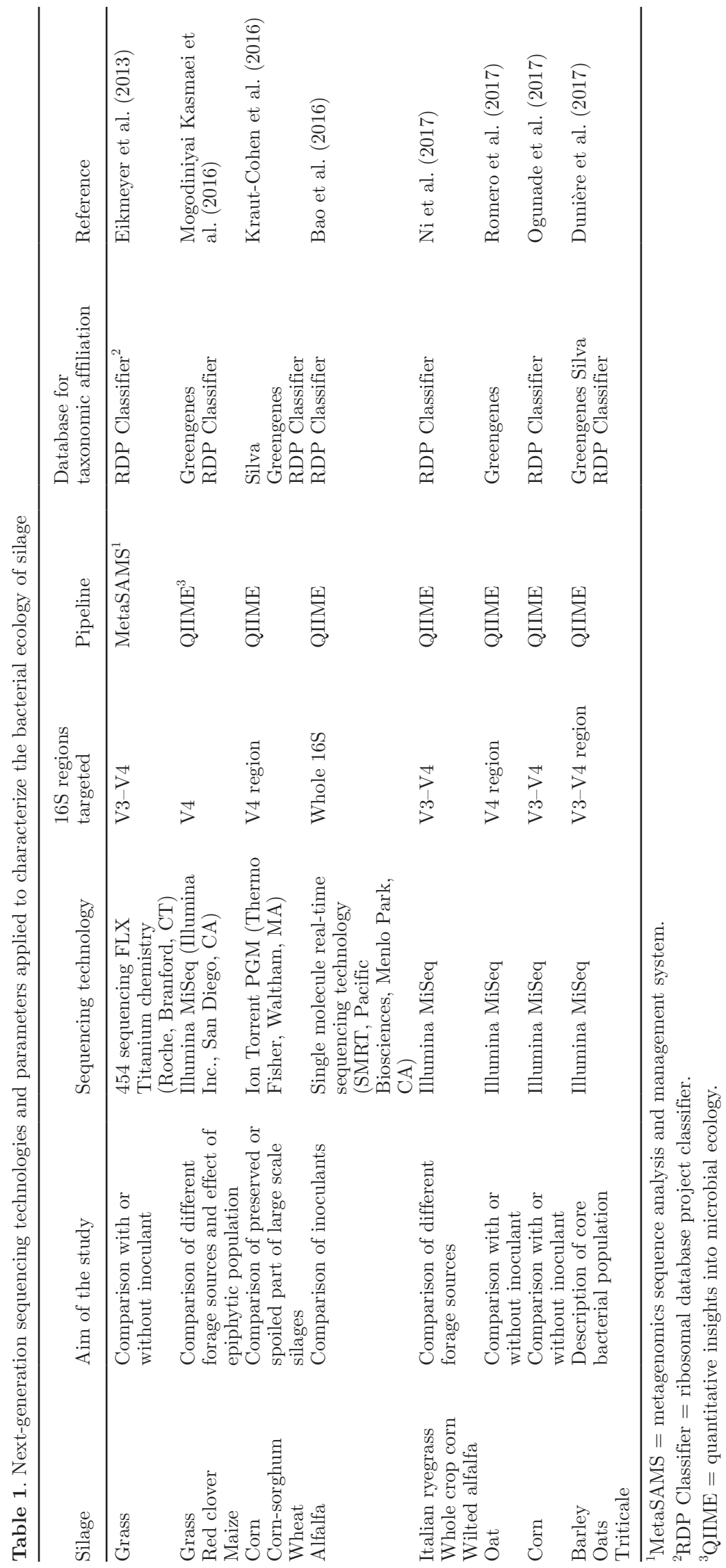


after 217 d (Romero et al., 2017). Finally, LAB accounted for $2 \%$ of the core bacterial microbiome of oat, barley, triticale or a mix of these forages at harvest, expanding to account for $83 \%$ of the core microbiome in these terminal small grain silages (Dunière et al., 2017). The dominance of LAB after ensiling is in agreement with previous researchers that have used earlier non-NGS to describe the bacterial communities associated with silage such as T-RFLP (McEniry et al., 2008, 2010) or DGGE (Parvin and Nishino 2009) as described above. The intensive selection process that enables LAB to predominate during ensiling is associated with the conditions promoted by good ensiling practices including the exclusion of oxygen and the rapid conversion of water-soluble carbohydrates to organic acids. Interestingly, ensiling populations associated with legume silages appear to be more diverse than those associated with cereal silages. For example, Enterococcaceae dominated bacterial populations associated with wilted alfalfa and accounted for almost 50\% of the bacterial population in terminal silage (Ni et al., 2017). However, in another study, members of the Lactobacillaceae accounted for a significant proportion of the bacterial population $(72.2 \%)$ in alfalfa ensiled for $40 \mathrm{~d}$, but members of Enterococcaceae were still readily apparent (McGarvey et al., 2013). When comparing the bacterial populations within preserved (center) and spoiled (adjacent to bunker walls) cereal silages stored in a bunker silo, the proportion of Lactobacillaceae decreased from 73 to $97 \%$ to less than $2 \%$ of the total bacterial population (KrautCohen et al., 2016). These authors observed that the microbiomes associated these samples exhibited a high degree of variation in bacterial diversity. Specifically,
Bacillus and Corynebacterium dominated in spoiled samples collected from one location, whereas Bacillus, Proteus, and Comamonas were most abundant in a sample from a second location, with Corynebacterium, Proteus, Comamonas, and Acetobacter being the most predominant genera in a sample from a third location. Consequently, even within a silo, it appears that subtle localized changes in the ensiling environment can cause significant shifts in the nature of the bacterial species associated with silage.

Addition of a silage inoculant generally decreases the bacterial diversity in terminal silage (Table 2) as observed in grass after $58 \mathrm{~d}$ of ensiling (Eikmeyer et al., 2013), corn silage after $120 \mathrm{~d}$ of ensiling (Ogunade et al., 2017), alfalfa after 35 d of ensiling (Bao et al., 2016), and oat after $217 \mathrm{~d}$ of ensiling (Romero et al., 2017). Silages inoculated with a single inoculant strain generally resulted in this bacterium being the predominant bacterial species in terminal silage. Noteworthy, when a mixed inoculant containing Pediococcus acidilactici was applied, the relative abundance of this species was the highest ( 74 to $86 \%$ ) in terminal silages (Bao et al., 2016). In contrast, application of $P$. pentosaceus to oat forage at ensiling did not result in this species being predominate in terminal silage (Romero et al., 2017). Thus, the effect of inoculants on the microbial ecology of silage can differ among inoculant species and with the type of crop ensiled.

To date, only one study has used NGS technologies to describe the nature of bacterial population during aerobic exposure. Dunière et al. (2017) observed a substantial increase (1 to $43 \%$ ) in members of Bacillales in small grain silages aerobically exposed for $14 \mathrm{~d}$. This

Table 2. Effect of inoculants on the bacterial ecology of silages

\begin{tabular}{|c|c|c|c|}
\hline $\begin{array}{l}\text { Silage } \\
\text { crop }\end{array}$ & Inoculants and application rate & $\begin{array}{l}\text { Relative abundance after } \\
\text { fermentation }\end{array}$ & Reference \\
\hline Grass & Lactobacillus buchneri CD034 at $10^{6} \mathrm{cfu} / \mathrm{g}$ & $\begin{array}{l}67 \% \text { Lactobacillus } \\
2 \% \text { Lactococcus } \\
2 \% \text { Leuconostoc } \\
2 \% \text { Weisella } \\
18 \% \text { phylum } \neq \text { Firmicutes }\end{array}$ & Eikmeyer et al. (2013) \\
\hline Corn & $\begin{array}{l}\text { Lactobacillus plantarum at } 10^{6} \mathrm{cfu} / \mathrm{g} \text { or } \\
\text { L. buchneri at } 10^{6} \mathrm{cfu} / \mathrm{g}\end{array}$ & $\begin{array}{l}98.3 \% \text { Lactobacillus } \\
0.98 \% \text { Proteobacteria } \\
94.8 \% \text { Lactobacillus } \\
2.63 \% \text { Proteobacteria }\end{array}$ & Ogunade et al. (2017) \\
\hline Alfalfa & $\begin{array}{l}\text { L. plantarum strain } 1 \text { at } 10^{5} \mathrm{cfu} / \mathrm{g} \\
\text { L. plantarum strain } 2 \text { at } 10^{5} \mathrm{cfu} / \mathrm{g}\end{array}$ & $\begin{array}{l}50 \% \text { L. plantarum } \\
40 \% \text { non-LAB }{ }^{1} \\
62 \% \text { L. plantarum } \\
23 \% \text { Lactobacillus pobuzihii } \\
15 \% \text { non-LAB }\end{array}$ & Bao et al. (2016) \\
\hline & $\begin{array}{l}\text { L. plantarum, Lactobacillus casei, Enterococcus faecium, } \\
\text { Pediococcus acidilactici at } 10^{5} \mathrm{cfu} / \mathrm{g} \\
\text { P. acidilactici, L. plantarum at } 10^{5} \mathrm{cfu} / \mathrm{g}\end{array}$ & $\begin{array}{l}74 \% \text { P. acidilactici } \\
18 \% \text { non-LAB } \\
86 \% \text { P. acidilactici } \\
6 \% \text { non-LAB }\end{array}$ & \\
\hline
\end{tabular}


increase was accompanied by a decrease of Lactobacillales, Enterobacteriales, Xanthomonadales, Rhizobiales, and Sphingomonadales in all spoiled silages. Others have also observed declines in Lactobacillales and increases in Bacillales when DGGE was used to characterize the bacterial populations associated with aerobically exposed corn silage (Dolci et al., 2011). Moreover, emergence of clostridia and bacilli were observed in bacterial DNA isolated from grass silages exposed to air using T-RFLP (McEniry et al., 2008) and DGGE (Li and Nishino, 2011b). In contrast, aerobic exposure was associated with an increase in lactobacilli and a decrease in bacterial diversity when $16 \mathrm{~S}$ rDNA clone libraries were used to characterize bacterial populations in alfalfa silage (McGarvey et al., 2013).

Research has also been undertaken to characterize the role of eukaryotic microorganisms in the ensiling process, with an emphasis on their contribution to the aerobic deterioration of silages (Dolci et al., 2011; Borreani et al., 2014), mycotoxin production (Gallo et al., 2015), and the associated risks to feed and food safety (Fink-Gremmels, 2008). Next-generation sequencing has been used to describe fungal populations in the rumen (Fouts et al., 2012), soil (Lim et al., 2010), compost (Neher et al., 2013), rhizosphere (Blaalid et al., 2012), and recently in silage residues used for composting and biogas production (Neher et al., 2013; Kazda et al., 2014). Samples in these studies consisted of a mixture of compost, manure, rotting vegetables, and spoiled silage, making it impossible to specifically identify silage-associated fungal species. To date, we are aware of only 2 publications that have used NGS to specifically characterize fungal populations in silage. Romero et al. (2017) sequenced the ITS1 region of the rDNA gene and assigned the sequences to a UNITE (User-friendly Nordic ITS Ectomycorrhiza Database) fungal ITS reference database. However, the taxonomic depth associated with pre-ensiled oats was low, as $56.9 \%$ of the sequences could not be assigned. The dominant fungal families within the Ascomycota included Davidiellaceae (26.9\%), Pleosporaceae (5.1\%), and Pleosporales (2.3\%). After ensiling, Ascomycota dominated the fungal population (97.4\%) and only $1.48 \%$ of the sequences remained unidentified. Pichiaceae (61.9\%), Trichocomaceae $(7.9 \%)$, and OTU belonging to Saccharomycetales order (13.9\%) were the main taxonomic groups identified. As Pichiaceae belong to the order Saccharomycetales, these results are in agreement with a recent study conducted in our laboratory (Dunière et al., 2017). Saccharomycetales accounted for the majority of the fungal core microbiome $(71 \%)$ in small grain silages after $90 \mathrm{~d}$ of ensiling. The relative abundance of some fungal species was altered by ensiling (e.g., Capnodiales, Tremellales, and Pucciniales), with relative abundances also differing among types of small grain silages.

We also explored the fungal core microbiome in small grain silage after $14 \mathrm{~d}$ of aerobic exposure. Saccharomycetales remained the dominant order in the fungal core microbiome (62\% Kazachstania; $8 \%$ Pichia), but the number of shared OTU among aerobically exposed silages dropped by almost $50 \%$. This indicated that the nature of the fungal communities that developed upon aerobic exposure depended heavily on the type of small grain silage. The dominance of Saccharomycetales has also been observed in other studies using molecular techniques to characterize fungal populations. After 7 $\mathrm{d}$ of aerobic exposure of inoculated corn silage, DGGE was used to identify several fungi with the predominant species differing among inoculant formulations and sampling times (Li and Nishino, 2011a). Fungal communities in ryegrass silage aerobically exposed for $7 \mathrm{~d}$ were shown to consist of Pichia anomala, Pichia burtonii, S. cerevisiae, and Penicillium roquefortii (Li and Nishino, 2011b).

Compared with bacterial populations, fungal populations do not undergo the same compositional transitions observed for bacteria as the acidic and anaerobic conditions are unfavorable for fungal growth (Romero et al., 2017). However, many fungal species appear to enter a dormant, but viable state during ensiling and become revitalized upon aerobic exposure.

Functional Sequencing. Although the majority of NGS studies have used amplicon sequencing to define the microbial ecology of silage, shotgun sequences offer advantages in that genes associated with both phylogeny and function are sequenced. Thus, specific genes involved in metabolic pathways can thus be targeted in an effort to understand their functional contribution to the ensiling process. Such approaches may have application in characterizing biochemical pathways involved in the production or degradation of mycotoxins during ensiling. For example, this approach has been used to evaluate the ability of the rat microbiome to detoxify ochratoxin A (Guo et al., 2014), a toxin that is commonly found in silage (Keller et al., 2013). However, to our knowledge, metagenomic sequencing studies focusing on functional aspects of the ensiling process have yet to be undertaken.

Functional sequencing using RNA samples (metatranscriptomic) has been used to assess the functional fibrolytic capacity of the rumen (Qi et al., 2011; Comtet-Marre et al., 2017). Similar techniques could be used in silage in several manners in an effort to improve the quality and safety of silage. For example, gene expression associated with mycotoxin formation and degradation could be investigated in an effort to identify approaches to reduce mycotoxin levels in 
silage. Expression of genes coding for antimicrobials such as bacteriocins could provide insight into reducing the occurrence of spoilage bacteria or those that pose a health threat (e.g., Listeria) in silage. Expression of genes coding for carbohydrate degradation could provide new insight into how enzymes involved in the plant cell wall degradation may be used to enhance the digestibility of silage. Characterizing differential expression among inoculants may shed insight into why certain strains more readily persist in silage than others or may possibly confer beneficial probiotic properties to the animal upon consumption.

Other techniques based on genomic-scale sequence enrichment through the use of complementary nucleic acid capture probes could enable rarer DNA sequences (Denonfoux et al., 2013) in silage to be characterized. This strategy using variant specific and explorative probes could increase sequence coverage of targeted regions and lower sequencing costs as compared with shotgun sequencing of total DNA from silage (Ribière et al., 2016).

\section{CONCLUSIONS}

Next-generation sequencing techniques are poised to revolutionize our understanding of the microbial ecology of ensiling and aerobic deterioration. Sampling, storage, nucleic acid extraction, sequencing, and bioinformatics techniques can all influence interpretation of the composition and function of microbial populations involved in ensiling. Caution should therefore be taken in extrapolating findings across silage studies where different methodologies have been employed. The sophistication and consistency of the tools to study microbiomes in a variety of environments are expanding exponentially. Subsequently, the robustness of the databases that play such a critical role in annotation will certainly continue to increase. The science of silage metagenomics has the potential to improve silage quality, safety, and further increase the efficacy and consistency of additives, enhancing the ensiling process.

\section{ACKNOWLEDGMENTS}

Some of the authors who contributed to the development of this review were supported in part by a grant from the Agriculture and Agri-Food Canada Growing Forward II Barley Cluster.

\section{REFERENCES}

Anderson, I., and J. Cairney. 2004. Diversity and ecology of soil fungal communities: Increased understanding through the application of molecular techniques. Environ. Microbiol. 6:769-779. https://doi .org/10.1111/j.1462-2920.2004.00675.x.
Anderson, I. C., C. D. Campbell, and J. I. Prosser. 2003. Potential bias of fungal $18 \mathrm{~S}$ rDNA and internal transcribed spacer polymerase chain reaction primers for estimating fungal biodiversity in soil. Environ. Microbiol. 5:36-47.

Ashwini, D., and S. P. Tiwari. 2015. Use of CTAB method for isolation of good quality and quantity of DNA. J. Pure Appl. Microbiol. 9:2271-2274.

Bahl, M. I., A. Bergstrom, and T. R. Licht. 2012. Freezing fecal samples prior to DNA extraction affects the Firmicutes to Bacteroidetes ratio determined by downstream quantitative PCR analysis. FEMS Microbiol. Lett. 329:193-197.

Baker, G. C., J. J. Smith, and D. A. Cowan. 2003. Review and reanalysis of domain-specific $16 \mathrm{~S}$ primers. J. Microbiol. Methods 55:541-555.

Bao, W., Z. Mi, H. Xu, Y. Zheng, L. Y. Kwok, H. Zhang, and W. Zhang. 2016. Assessing quality of Medicago sativa silage by monitoring bacterial composition with single molecule, real-time sequencing technology and various physiological parameters. Sci. Rep. 6:28358. https://doi.org/10.1038/srep28358.

Bellemain, E., T. Carlsen, C. Brochmann, E. Coissac, P. Taberlet, and H. Kauserud. 2010. ITS as an environmental DNA barcode for fungi: An in silico approach reveals potential PCR biases. BMC Microbiol. 10:189. https://doi.org/10.1186/1471-2180-10-189.

Blaalid, R., T. Carlsen, S. Kumar, H. Halvorsen, K. I. Ugland, G. Fontana, and H. Kauserud. 2012. Changes in the root-associated fungal communities along a primary succession gradient analysed by 454 pyrosequencing. Mol. Ecol. 21:1897-1908.

Bogino, P. C., M. M. Oliva, F. G. Sorroche, and W. Giordano. 2013. The role of bacterial biofilms and surface components in plantbacterial associations. Int. J. Mol. Sci. 14:15838-15859. https:// doi.org/10.3390/ijms140815838.

Borreani, G., S. Piano, and E. Tabacco. 2014. Aerobic stability of maize silage stored under plastic films with different oxygen permeability. J. Sci. Food Agric. 94:2684-2690. https://doi.org/10 $.1002 /$ jsfa.6609.

Brusetti, L., S. Borin, A. Rizzi, D. Mora, C. Sorlini, and D. Daffonchio. 2008. Exploration of methods used to describe bacterial communities in silage of maize (Zea mays) cultivars. Environ. Biosafety Res. 7:25-33. https://doi.org/10.1051/ebr:2007047.

Bulgarelli, D., M. Rott, K. Schlaeppi, E. Ver Loren van Themaat, N. Ahmadinejad, F. Assenza, P. Rauf, B. Huettel, R. Reinhardt, E. Schmelzer, J. Peplies, F. O. Gloeckner, R. Amann, T. Eickhorst, and P. Schulze-Lefert. 2012. Revealing structure and assembly cues for arabidopsis root-inhabiting bacterial microbiota. Nature 488:91-95. https://doi.org/10.1038/nature11336.

Case, R. J., Y. Boucher, I. Dahllöf, C. Holmström, W. F. Doolittle, and S. Kjelleberg. 2007. Use of $16 \mathrm{~S}$ rRNA and rpoB genes as molecular markers for microbial ecology studies. Appl. Environ. Microbiol. 73:278-288. https://doi.org/10.1128/AEM.01177-06.

Chakravorty, S., D. Helb, M. Burday, N. Connell, and D. Alland. 2007. A detailed analysis of $16 \mathrm{~S}$ ribosomal RNA gene segments for the diagnosis of pathogenic bacteria. J. Microbiol. Methods 69:330-339.

Chase, M., and M. Fay. 2009. Barcoding of plants and fungi. Science 325:682-683. https://doi.org/10.1126/science.1176906.

Claesson, M. J., O. O'Sullivan, Q. Wang, J. Nikkila, J. R. Marchesi, H. Smidt, W. M. de Vos, R. P. Ross, and P. W. O'Toole. 2009. Comparative analysis of pyrosequencing and a phylogenetic microarray for exploring microbial community structures in the human distal intestine. PLoS One 4:e6669.

Comtet-Marre, S., N. Parisot, P. Lepercq, F. Chaucheyras-Durand, P. Mosoni, E. Peyretaillade, A. R. Bayat, K. J. Shingfield, P. Peyret, and E. Forano. 2017. Metatranscriptomics reveals the active bacterial and eukaryotic fibrolytic communities in the rumen of dairy cow fed a mixed diet. Front. Microbiol. 8:67. https://doi.org/10 $.3389 /$ fmicb.2017.00067.

Denonfoux, J., N. Parisot, E. Dugat-Bony, C. Biderre-Petit, D. Boucher, D. P. Morgavi, D. Le Paslier, E. Peyretaillade, and P. Peyret. 2013. Gene capture coupled to high-throughput sequencing as a strategy for targeted metagenome exploration. DNA Res. 20:185196. https://doi.org/10.1093/dnares/dst001. 
Dolci, P., E. Tabacco, L. Cocolin, and G. Borreani. 2011. Microbial dynamics during aerobic exposure of corn silage stored under oxygen barrier or polyethylene films. Appl. Environ. Microbiol. 77:7499 7507. https://doi.org/10.1128/AEM.05050-11.

Dunière, L., L. Jin, M. Qi, W. Rutherford, Y. Wang, and T. McAllister. 2015. Impact of adding Saccharomyces strains on fermentation, aerobic stability, nutritive value and lactobacilli populations in corn silage. J. Anim. Sci. 93:2322-2335. https://doi.org/ $10.2527 /$ jas. 2014-8287.

Dunière, L., S. Xu, L. Jin, C. Elekwachi, Y. Wang, K. Tukington, R. Forster, and T. A. McAllister. 2017. Bacterial and fungal core microbiomes associated with small grain silages during ensiling and aerobic spoilage. BMC Microbiol. 17:50. https://doi.org/10.1186/ s12866-017-0947-0.

Eikmeyer, F. G., P. Köfinger, A. Poschenel, S. Jünemann, M. Zakrzewski, S. Heinl, E. Mayrhuber, R. Grabherr, A. Pühler, H. Schwab, and A. Schlüter. 2013. Metagenome analyses reveal the influence of the inoculant Lactobacillus buchneri CD034 on the microbial community involved in grass ensiling. J. Biotechnol. 167:334-343. https://doi.org/10.1016/j.jbiotec.2013.07.021.

Fink-Gremmels, J. 2008. Mycotoxins in cattle feeds and carry-over to dairy milk: A review. Food Addit. Contam. Part A Chem. Anal. Control Expo. Risk Assess. 25:172-180. https://doi.org/10.1080/ 02652030701823142.

Flygare, S., K. Simmon, C. Miller, Y. Qiao, B. Kennedy, T. Di Sera, E. H. Graf, K. D. Tardif, A. Kapusta, S. Rynearson, C. Stockmann, K. Queen, S. Tong, K. V. Voelkerding, A. Blaschke, C. L. Byington, S. Jain, A. Pavia, K. Ampofo, K. Eilbeck, G. Marth, M. Yandell, and R. Schlaberg. 2016. Taxonomer: an interactive metagenomics analysis portal for universal pathogen detection and host mRNA expression profiling. Genome Biol. 17:111. https://doi .org/10.1186/s13059-016-0969-1.

Fouts, D. E., S. Szpakowski, J. Purushe, M. Torralba, R. C. Waterman, M. D. MacNeil, L. J. Alexander, and K. E. Nelson. 2012. Next generation sequencing to define prokaryotic and fungal diversity in the bovine rumen. PLoS One 7:e48289. https://doi.org/10 .1371/journal.pone.0048289.

Furet, J. P., P. Quenee, and P. Tailliez. 2004. Molecular quantification of lactic acid bacterial in fermented milk porducts using real-time PCR. Int. J. Food Microbiol. 97:197-207.

Gallo, A., G. Giuberti, J. C. Frisvad, T. Bertuzzi, and K. F. Nielsen. 2015. Review on mycotoxin issues in ruminants: Occurrence in forages, effects of mycotoxin ingestion on health status and animal performance and practical strategies to counteract their negative effects. Toxins (Basel) 7:3057-3111. https://doi.org/10.3390/ toxins 7083057 .

Guo, M., K. Huang, S. Chen, X. Qi, X. He, W.-H. Cheng, Y. Luo, K. Xia, and W. Xu. 2014. Combination of metagenomics and culture-based methods to study the interaction between ochratoxin A and gut microbiota. Toxicol. Sci. 141:314-323. https://doi.org/ $10.1093 /$ toxsci/kfu128.

Gürtler, V., and V. A. Stanisich. 1996. New approaches to typing and identification of bacteria using the $16 \mathrm{~S}-23 \mathrm{~S}$ rDNA spacer region. Microbiology 142:3-16.

Henderson, G., F. Cox, S. Kittelmann, V. H. Miri, M. Zethof, S. J. Noel, G. C. Waghorn, and P. H. Janssen. 2013. Effect of DNA extraction methods and sampling techniques on the apparent structure of cow and sheep rumen microbial communities. PLoS One 8:e74787. https://doi.org/10.1371/journal.pone.0074787.

Hess, M., A. Sczyrba, R. Egan, T-W. Kim, H. Chokhawala, G. Schroth, S. Luo, D. S. Clark, F. Chen, T. Zhang, R. I. Mackie, L. A. Pennacchio, S. G. Tringe, A. Visel, T. Woyke, Z. Wang, and E. M. Rubin. 2011. Metagenomic discovery of biomass-degrading genes and genomes from cow rumen. Science 331:463-467. https:// doi.org/10.1126/science.1200387.

Hofstatter, P. G., A. K. Tice, S. Kang, M. W. Brown, and D. J. G. Lahr. 2016. Evolution of bacterial recombinase A (recA) in eukaryotes explained by addition of genomic data by key microbial lineages. Proc. Biol. Sci. 283: https://doi.org/10.1098/rspb.2016 .1453
Horton, T., and T. Bruns. 2001. The molecular revolution in ectomycorrhizal ecology: Peeking into the black box. Mol. Ecol. 10:18551871. https://doi.org/10.1046/j.0962-1083.2001.01333.x.

Huse, S. M., L. Dethlefsen, J. A. Huber, D. Mark Welch, D. A. Relman, and M. L. Sogin. 2008. Exploring microbial diversity and taxonomy using SSU rRNA hypervariable tag sequencing. PLoS Genet. 4:e1000255.

Huws, S. A., E. J. Kim, S. J. S. Cameron, S. E. Girdwood, L. Davies, J. Tweed, H. Vallin, and N. D. Scollan. 2015. Characterization of the rumen lipidome and microbiome of steers fed a diet supplemented with flax and echium oil. Microb. Biotechnol. 8:331-341. https://doi.org/10.1111/1751-7915.12164.

Julien, M.-C., P. Dion, C. Lafrenière, H. Antoun, and P. Drouin. 2008 Sources of Clostridia in raw milk on farms. Appl. Environ. Microbiol. 74:6348-6357.

Kazda, M., S. Langer, and F. R. Bengelsdorf. 2014. Fungi open new possibilities for anaerobic fermentation of organic residues. Energy Sustain. Soc. 4:6. https://doi.org/10.1186/2192-0567-4-6.

Keller, L. A. M., M. L. González Pereyra, K. M. Keller, V. A. Alonso, A. A. Oliveira, T. X. Almeida, T. S. Barbosa, L. M. T. Nunes, L. R. Cavaglieri, and C. A. R. Rosa. 2013. Fungal and mycotoxins contamination in corn silage: Monitoring risk before and after fermentation. J. Stored Prod. Res. 52:42-47. https://doi.org/10 $.1016 / j . j s p r .2012 .09 .001$

Keshri, J., A. Mishra, and B. Jha. 2013. Microbial population index and community structure in saline-alkaline soil using gene targeted metagenomics. Microbiol. Res. 168:165-173. https://doi.org/10 .1016/j.micres.2012.09.005.

Klocke, M., K. Mundt, C. Idler, J. McEniry, P. O'Kiely, and S. Barth. 2006. Monitoring Lactobacillus plantarum in grass silages with the aid of $16 \mathrm{~S}$ rDNA-based quantitative real-time PCR assays. Syst. Appl. Microbiol. 29:49-58.

Kraut-Cohen, J., V. Tripathi, Y. Chen, J. Gatica, V. Volchinski, S. Sela, Z. Weinberg, and E. Cytryn. 2016. Temporal and spatial assessment of microbial communities in commercial silages from bunker silos. Appl. Microbiol. Biotechnol. 100:6827-6835. https:// doi.org/10.1007/s00253-016-7512-x.

Kumar, M. S., G. Kaur, and A. K. Sandhu. 2014. Genomic DNA isolation from fungi, algal, plant bacteria and human blood using CTAB. Int. J. Sci. Res. 3:617-618.

Lane, D. J., B. Pace, G. J. Olsen, D. A. Stahl, M. L. Sogin, and N. R. Pace. 1985. Rapid determination of $16 \mathrm{~S}$ ribosomal RNA sequences for phylogenetic analyses. Proc. Natl. Acad. Sci. USA 82:6955-6959.

Langille, M. G. I., J. Zaneveld, J. G. Caporaso, D. McDonald, D. Knights, J. A. Reyes, J. C. Clemente, D. E. Burkepile, R. L. Vega Thurber, R. Knight, R. G. Beiko, and C. Huttenhower. 2013. Predictive functional profiling of microbial communities using $16 \mathrm{~S}$ rRNA marker gene sequences. Nat. Biotechnol. 31:814-821.

Langston, C. W., and C. Bouma. 1960a. Types and sequence change of bacteria in orchard grass and alfalfa silage. J. Dairy Sci. 43:15751584 .

Langston, C. W., and C. Bouma. 1960b. A study of microorganisms on grass silage. I. The cocci. Appl. Microbiol. 8:212-222.

Langston, C. W., and C. Bouma. 1960c. A study of microorganisms on grass silage. II. The lactobacilli. Appl. Microbiol. 8:223-234.

Lauber, C. L., N. Zhou, J. I. Gordon, R. Knight, and N. Fierer. 2010. Effect of storage conditions on the assessment of bacterial community structure in soil and human-associated samples. FEMS Microbiol. Lett. 307:80-86.

Li, Y., and N. Nishino. 2011a. Bacterial and fungal communities of wilted Italian ryegrass silage inoculated with and without Lactobacillus rhamnosus or Lactobacillus buchneri. Lett. Appl. Microbiol. 52:314-321. https://doi.org/10.1111/j.1472-765X.2010.03000.x.

Li, Y., and N. Nishino. 2011b. Effects of inoculation of Lactobacillus rhamnosus and Lactobacillus buchneri on fermentation, aerobic stability and microbial communities in whole crop corn silage. Grassl. Sci. 57:184-191. https://doi.org/10.1111/j.1744-697X.2011 $.00226 . x$

Lim, Y. W., B. K. Kim, C. Kim, H. S. Jung, B.-S. Kim, J.-H. Lee, and J. Chun. 2010. Assessment of soil fungal communities using py- 
rosequencing. J. Microbiol. 48:284-289. https://doi.org/10.1007/ s12275-010-9369-5.

Lindahl, B. D., R. H. Nilsson, L. Tedersoo, K. Abarenkov, T. Carlsen, R. Kjoller, U. Koljalg, T. Pennanen, S. Rosendahl, J. Stenlid, and H. Kauserud. 2013. Fungal community analysis by high-throughput sequencing of amplified markers-A user's guide. New Phytol. 199:288-299. https://doi.org/10.1111/nph.12243.

Links, M. G., T. J. Dumonceaux, S. H. Hemmingsen, and J. E. Hill. 2012. The Chaperonin-60 universal target is a barcode for bacteria that enables de novo assembly of metagenomic sequence data. PLoS One 7:e49755. https://doi.org/10.1371/journal.pone .0049755 .

Liu, Q. H., T. Shao, and J. G. Zhang. 2013. Determination of aerobic deterioriation of corn stalk silage caused by aerobic bacteria. Anim. Feed Sci. Technol. 183:124-131.

Liu, Z., T. Z. DeSantis, G. L. Andersen, and R. Knight. 2008. Accurate taxonomy assignments from $16 \mathrm{~S}$ rRNA sequences produced by highly parallel pyrosequencers. Nucleic Acids Res. 36:e120.

Logares, R., S. Sunagawa, G. Salazar, F. M. Cornejo-Castillo, I. Ferrera, H. Saremento, P. Hingamp, H. Ogata, C. de Vargas, G. LimaMendez, J. Raes, J. Poulain, O. Jaillon, P. Wincker, S. KandelsLewis, E. Karsenti, P. Bork, and S. G. Acinas. 2014. Metagenomic $16 \mathrm{~S}$ rDNA Illumina tags are a powerful alternative to amplicon sequencing to explore diversity and structure of microbial communities. Environ. Microbiol. 16:2659-2671. https://doi.org/10.1111/ 1462-2920.12250.

Love, D. C., M. J. Casteel, J. S. Meschke, and M. D. Sobsey. 2008. Methods for recovery of hepatitis A virus (HAV) and other viruses from processed foods and detection of HAV by nested RT-PCR and TaqMan RT-PCR. Int. J. Food Microbiol. 126:221-226.

Lynch, J. P., P. O'Kiely, S. M. Waters, and E. M. Doyle. 2012. Conservation characteristics of corn ears and stover ensiled with the addition of Lactobacillus plantarum MTD-1, Lactobacillus plantarum 30114 or Lactobacillus buchneri 11A44. J. Dairy Sci. 95:2070-2080. https://doi.org/10.3168/jds.2011-5013.

Martinez Tuppia, C., V. Atanasova-Penichon, S. Chéreau, N. Ferrer, G. Marchegay, J.-M. Savoie, and F. Richard-Forget. 2017. Yeast and bacteria from ensiled high moisture maize grains as potential mitigation agents of fuminisin B1. J. Sci. Food Agric. 97:24432452. https://doi.org/10.1002/jsfa.8058.

McAllister, T. A., H. D. Bae, G. A. Jones, and K.-J. Cheng. 1994. Microbial attachment and feed digestion in the rumen. J. Anim. Sci. 72:3004-3018

McCabe, K. M., Y. H. Zhang, B. L. Huang, E. A. Wagar, and E. R. McCabe. 1999. Bacterial species identification after DNA amplification with a universal primer pair. Mol. Genet. Metab. 66:205211.

McEniry, J., P. O'Kiely, N. J. W. Clipson, P. D. Forristal, and E. M. Doyle. 2008. Bacterial community dynamics during the ensilage of wilted grass. J. Appl. Microbiol. 105:359-371. https://doi.org/10 .1111/j.1365-2672.2008.03802.x.

McEniry, J., P. O'Kiely, N. J. W. Clipson, P. D. Forristal, and E. M. Doyle. 2010. Assessing the impact of various ensilage factors on the fermentation of grass silage using conventional culture and bacterial community analysis techniques. J. Appl. Microbiol. 108:1584-1593.

McGarvey, J. A., R. B. Franco, J. D. Palumbo, R. Hnasko, L. Stanker, and F. M. Mitloehner. 2013. Bacterial population dynamics during the ensiling of Medicago sativa (alfalfa) and subsequent exposure to air. J. Appl. Microbiol. 114:1661-1670. https://doi.org/10 $.1111 /$ jam.12179.

Mogodiniyai Kasmaei, K., J. Dicksved, R. Spörndly, and P. Udén. 2016. Separating the effects of forage source and field microbiota on silage fermentation quality and aerobic stability. Grass Forage Sci. 72:281-289.

Molbak, L., H. M. Sommer, K. Johnsen, M. Boye, M. Johansen, K. Moller, and T. D. Leser. 2006. Freezing at -20 degrees C distorts the DNA composition of bacterial communities in intestinal samples. Curr. Issues Intest. Microbiol. 7:29-34. https://doi.org/ $10.1111 /$ gfs. 12238 .
Muck, R. E. 2013. Recent advances in silage microbiology. Agric. Food Sci. 22:3-15.

Myer, P. R., M. Kim, H. C. Freetly, and T. P. Smith. 2016. Evaluation of $16 \mathrm{~S}$ rRNA amplicon sequencing using two next-generation sequencing technologies for phylogenetic analysis of the rumen bacterial community in steers. J. Microbiol. Methods 127:132-140.

Neher, D. A., T. R. Weicht, S. T. Bates, J. W. Leff, and N. Fierer. 2013. Changes in bacterial and fungal communities across compost recipes, preparation methods, and composting times. PLoS One 8:e79512. https://doi.org/10.1371/journal.pone.0079512.

Ni, K., T. T. Minh, T. T. Minh Tu, T. Tsuruta, H. Pang, and N. Nishino. 2017. Comparative microbiota assessment of wilted Italian ryegrass, whole crop corn, and wilted alfalfa silage using denaturing gradient gel electrophoresis and next-generation sequencing. Appl. Microbiol. Biotechnol. 101:1385-1394. https://doi.org/ 10.1007/s00253-016-7900-2.

Ogunade, I. M., Y. Jiang, D. H. Kim, A. A. Pech Cervantes, K. G. Arriola, D. Vyas, Z. G. Weinberg, K. C. Jeong, and A. T. Adesogan. 2017. Fate of Escherichia coli O157:H7 and bacterial diversity in corn silage contaminated with the pathogen and treated with chemical or microbial additives. J. Dairy Sci. 100:1780-1794. https://doi.org/10.3168/jds.2016-11745.

Ounit, R., S. Wanamaker, T. J. Close, and S. Lonardi. 2015. CLARK: fast and accurate classification of metagenomic genomic sequences using discriminative k-mers. BMC Genomics 16:236. https://doi .org/10.1186/s12864-015-1419-2.

Pahlow, G., R. E. Muck, and F. Driehuis. 2003. Microbiology of ensiling. Pages 31-93 in Silage Science and Technology. D. R. Buxton, R. E. Muck, and J. H. Harrison, ed. Monograph No. 42. American Society of Agronomy, Madison, WI.

Pakpour, S., S. V. Olishevska, S. O. Prasher, A. S. Milani, and M. R. Chénier. 2013. DNA extraction method selection for agricultural soil using TOPSIS multiple criteria decision-making model. Am. J. Mol. Biol. 3:215-228. https://doi.org/10.4236/ajmb.2013.34028.

Parvin, S., and N. Nishino. 2009. Bacterial community associated with ensilage process of wilted guinea grass. J. Appl. Microbiol. 107:2029-2036. https://doi.org/10.1111/j.1365-2672.2009.04391.x.

Pedro, M. S., S. Haruta, M. Hazaka, R. Shimada, C. Yoshida, K. Hiura, M. Ishii, and Y. Igarashi. 2001. Denaturing gradient gel electrophoresis analysis of microbial community from field-scale composter. J. Biosci. Bioeng. 91:159-165.

Pinto, A. J., and L. Raskin. 2012. PCR biases distort bacterial and archaeal community structure in pyrosequencing datasets. PLoS One 7:e43093.

Qi, M., P. Wang, N. O'Toole, P. S. Barboza, E. Ungerfeld, M. B. Leigh, L. B. Selinger, G. Butler, A. Tsang, T. A. McAllister, and R. J. Forster. 2011. Snapshot of the eukaryotic gene expression in muskoxen rumen-A metatranscriptomic approach. PLoS One 6:e20521. https://doi.org/10.1371/journal.pone.0020521.

Reuter, T., W. Xu, T. W. Alexander, K. Stanford, Y. Xu, and T. A. McAllister. 2009. Purification of polymerase chain reaction (PCR)-amplifiable DNA from compost piles containing bovine mortalities. Bioresour. Technol. 100:3343-3349.

Ribière, C., R. Beugnot, N. Parisot, C. Gasc, C. Defois, J. Denonfoux, D. Boucher, E. Peyretaillade, and P. Peyret. 2016. Targeted gene capture by hybridization to illuminate ecosystem functioning. Methods Mol. Biol. 1399:167-182. https://doi.org/10.1007/978-1 -4939-3369-3_10.

Romero, J. J., Y. Zhao, M. A. Balseca-Paredes, F. Tiezzi, E. Gutierrez-Rodriguez, and M. S. Castillo. 2017. Laboratory silo type and inoculation effects on nutritional composition, fermentation, and bacterial and fungal communities of oat silage. J. Dairy Sci. 100:1812-1828. https://doi.org/10.3168/jds.2016-11642.

Rossi, F., and F. Dellaglio. 2007. Quality of silages from Italian farms as attested by number and identity of microbial indicators. J. Appl. Microbiol. 103:1707-1715.

Rubin, B. E. R., S. M. Gibbons, S. Kennedy, J. Hampton-Marcell, S. Owens, and J. A. Gilbert. 2013. Investigating the impact of storage conditions on microbial community composition in soil samples. PLoS One 8:e70460. https://doi.org/10.1371/journal .pone.0070460. 
Schmidt, R. J., M. G. Emara, and L. Kung Jr.. 2008. The use of quantitative real-time polymerase chain reaction assay for identification and enumeration of Lactobacillus buchneri in silage. J. Appl. Microbiol. 105:920-929.

Schoch, C. L., K. A. Seifert, S. Huhndorf, V. Robert, J. L. Spouge, C. A. Levesque, and W. Chen. 2012. Nuclear ribosomal internal transcribed spacer (ITS) region as a universal DNA barcode marker for fungi. Proc. Natl. Acad. Sci. USA 109:6241-6246. https://doi.org/ $10.1073 /$ pnas.1117018109.

Schrader, C., A. Schielke, L. Ellerbroek, and R. Johne. 2012. PCR inhibitors-Occurrence, properties and removal. J. Appl. Microbiol. 113:1014-1026. https://doi.org/10.1111/j.1365-2672.2012.05384.x.

Steinbock, L. J., and A. Radenovic. 2015. The emergence of nanopores in next-generation sequencing. Nanotechnology 26:074003. https://doi.org/10.1088/0957-4484/26/7/074003.

Stevenson, D. M., R. E. Muck, K. J. Shineers, and P. J. Weimer. 2006. Use of real time PCR to determine populaiton profiles of individual species of lactic acid bacteria in alfalfa silage and stored corn stover. Appl. Microbiol. Biotechnol. 71:329-338. https://doi .org/10.1007/s00253-005-0170-z.

Streets, A. M., X. Zhang, C. Cao, Y. Pang, X. Wu, L. Xiong, L. Yang, Y. Fu, L. Zhao, F. Tang, and Y. Hunag. 2014. Microfluidic singlecell whole transcriptome sequencing. Proc. Natl. Acad. Sci. USA 111:7048-7053. https://doi.org/10.1073/pnas.1402030111.

Sundquist, A., S. Bigdeli, R. Jalili, M. L. Druzin, S. Waller, K. M. Pullen, Y. Y. El-Sayed, M. M. Taslimi, S. Batzoglou, and M. Ronaghi. 2007. Bacterial flora-typing with targeted, chip-based pyrosequencing. BMC Microbiol. 7:108.

Tennant, R. K., C. M. Sambles, G. E. Diffey, K. A. Moore, and J. Love. 2017. Metagenomic analysis of silage. J. Vis. Exp. 119:e54936. https://doi.org/10.3791/54936.

Thomas, T., J. Gilbert, and F. Meyer. 2012. Metagenomics-A guide from sampling to data analysis. Microb. Inform. Exp. 2:3. https:/ doi.org/10.1186/2042-5783-2-3.

Tonge, D. P., C. H. Pashley, and T. W. Gant. 2014. Amplicon-based metagenomic analysis of mixed fungal samples using proton release amplicon sequencing. PLoS One 9:e93849. https://doi.org/10 .1371/journal.pone.0093849.

Undersander, D., R. Shaver, J. Linn, P. Hoffman, and P. Peterson. 2005. Sampling hay, silage and total mixed rations for analysis. Cooperative Extension of the University of Wisconsin. https:// cecommerce.uwex.edu.
Van de Peer, Y., S. Chapelle, and R. De Wachter. 1996. A quantitative map of nucleotide substitution rates in bacterial rRNA. Nucleic Acids Res. 24:3381-3391.

Vinje, H., K. H. Liland, T. Almøy, and L. Snipen. 2015. Comparing K-mer based methods for improved classification of $16 \mathrm{~S}$ sequences. BMC Bioinformatics 16:205.

Vishnivetskaya, T. A., A. C. Layton, M. C. Y. Lau, A. Chauhan, K. R Cheng, A. J. Meyers, J. R. Murphy, A. W. Rogers, G. S. Saarunya D. E. Williams, S. M. Pfiffner, J. P. Biggerstaff, B. T. Stackhouse, T. J. Phelps, L. Whyte, G. S. Sayler, and T. C. Onstott. 2014 Commercial DNA extraction kits impact observed microbial community composition in permafrost samples. FEMS Microbiol. Ecol. $87: 217-230$.

Wang, P., M. Qi, P. Barboza, M. B. Leigh, E. Ungerfeld, L. B. Selinger, T. A. McAllister, and R. J. Forster. 2011. Isolation of high-quality total RNA from rumen anaerobic bacteria and fungi and subsequent detection of glycoside hydrolases. Can. J. Microbiol. 57:590598. https://doi.org/10.1139/w11-048.

Wang, Q., G. M. Garrity, J. M. Tiedje, and J. R. Cole. 2007. Naive Bayesian classifier for rapid assignment of rRNA sequences into the new bacterial taxonomy. Appl. Environ. Microbiol. 73:5261-5267.

White, T. J., T. Bruns, S. Lee, and J. W. Taylor. 1990. Amplification and direct sequencing of fungal ribosomal RNA genes for phylogenetics. Pages 315-322 in PCR Protocols: A Guide to Methods and Applications. M. A. Innis, D. H. Gelfand, J. J. Sninsky, and T. J. White, ed. Academic Press Inc., New York, NY.

Wood, D. E., and S. L. Salzberg. 2014. Kraken: Ultrafast metagenomic sequence classification using exact alignments. Genome Biol. 15:R46. https://doi.org/10.1186/gb-2014-15-3-r46.

Wu, B., Q. Zhang, Z. Liu, Z. Yu, and N. Nishino. 2014. Bacterial communities in alfalfa and corn silages produced in large scale and bunker silos in China. Japan Soc. Grassland Sci. 60:247-251.

Yang, B., Y. Wang, and P. Y. Qian. 2016. Sensitivity and correlation of hypervariable regions in $16 \mathrm{~S}$ rRNA genes in phylogenetic analysis. BMC Bioinformatics 17:135. https://doi.org/10.1186/s12859 -016-0992-y.

Zhou, Y., P. Drouin, and C. Lafrenière. 2016. Effect of temperature $\left(5-25^{\circ} \mathrm{C}\right)$ on epiphytic lactic acid bacteria populations and fermentation of whole-plant corn silage. J. Appl. Microbiol. 121:657-671. 